Keywords: Gloveboxes,

Polymers, Gloves,

Mechanical Properties,

Tensile Testing

Retention: 25 yrs-10561

SRNL-STI-2012-00069

\title{
Characterization of Tensile Strength of Glovebox Gloves
}

\author{
P.S. Korinko \\ Y. Breakiron \\ G. K. Chapman
}

February 29, 2012

\section{We Put Science To Work"}

The Savannah River National Laboratory is managed and operated for the U.S. Department of Energy by

SA VAN NAH RIVER N UCLEARSOLUTIONS, LLC

AIKEN, SC USA $29808 \bullet$ SRNL.DOE.GOV 
This Page Intentionally Left Blank 


\section{SRNL-STI-2012-00069 \\ Characterization of Tensile Strength of Glovebox Gloves}

Approvals:

Signature on file

2-28-2012

P. S. Korinko, Author

Materials Compatibility and Welding Technology

Signature on file

G.K. Chapman, Author

Materials Compatibility and Welding Technology

Signature on file

‘

Y. Breakiron, Author

$3-5-2012$

Tritium Engineering Intern, Clemson University

Signature on file

E. A. Clark, Technical Review

Materials Compatibility and Welding Technology

$3-5-12$

$3+5-2012$

Signature on file

T. M. Adams, Manager

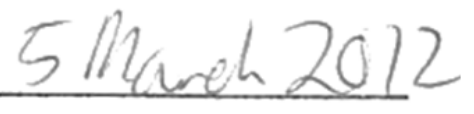

Materials Compatibility and Welding Technology 


\section{Table of Contents}

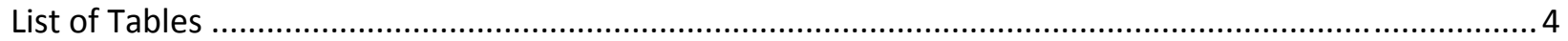

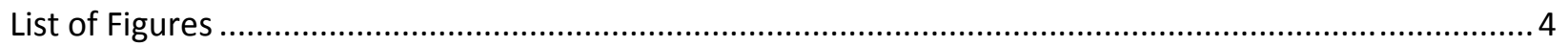

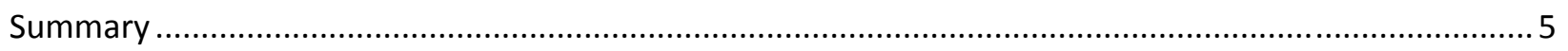

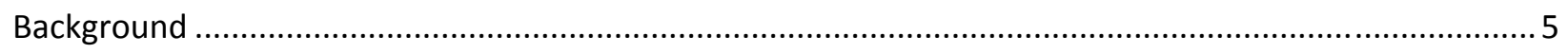

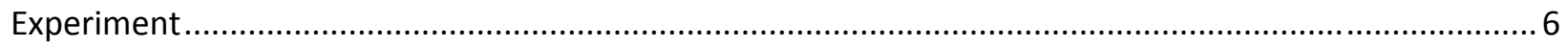

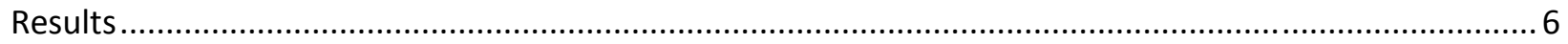

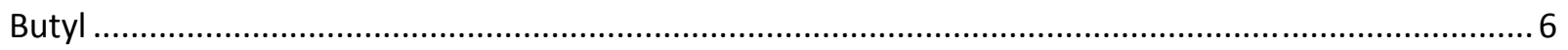

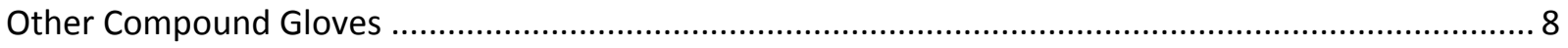

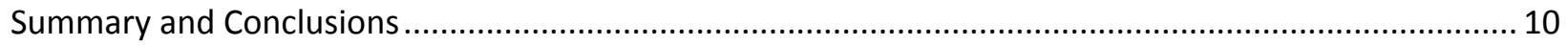

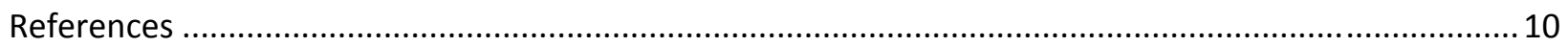

\section{List of Tables}

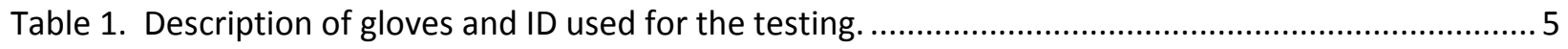

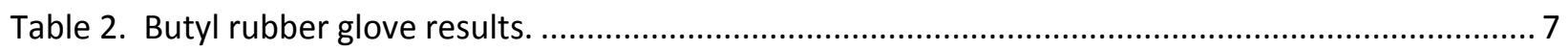

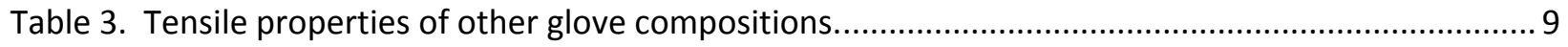

Table 4. Property requirements for selected gloves (2) ....................................................................... 9

\section{List of Figures}

Figure 1. Typical load, stress, and elongation results for North butyl rubber glove material. ................... 7

Figure 2. Stress strain results for three North Butyl rubber gloves. ....................................................... 7

Figure 3. Comparison of tensile load of Butyl rubber gloves............................................................ 8

Figure 4. Comparison of breaking force of other glove compositions................................................... 9 


\section{SRNL-STI-2012-00069}

\section{Characterization of Tensile Strength of Glovebox Gloves}

\section{Summary}

A task was undertaken to compare various properties of different glovebox gloves, having various compositions, for use in gloveboxes at the Savannah River Site (SRS). One aspect of this project was to determine the tensile strength (TS) of the gloves. Longitudinal tensile samples were cut from 15 different gloves and tensile tested. The stress, load, and elongation at failure were determined. All of the gloves that are approved for glovebox use and listed in the glovebox procurement specification met the tensile and elongation requirements. The Viton compound gloves are not listed in the specification, but exhibited lower tensile strengths than permissible based on the Butyl rubber requirements. Piercan Polyurethane gloves were the thinnest samples and exhibited the highest tensile strength of the materials tested.

\section{Background}

Four vendors provided a total of 15 different gloves for permeation testing, Thermogravimetric Analysis (TGA), Dynamic Mechanical Analysis (DMA), puncture testing, and tensile testing. In the study reported here, gloves from the vendors North, Piercan, Guardian, and Jung have been tensile tested. The composition and thickness of the gloves are listed in Table 1. Butyl gloves are the baseline gloves currently used in the Tritium Facility. These gloves have very good hydrogen and air permeation resistance but suffer from somewhat poor abrasion resistance. The tests reported here were performed to measure the mechanical properties of the gloves.

Table 1. Description of gloves and ID used for the testing.

\begin{tabular}{|c|c|c|c|c|c|c|c|}
\hline Vendor & Composition & $\begin{array}{l}\text { Thickness } \\
\text { (mils) }\end{array}$ & ID & Vendor & Composition & $\begin{array}{l}\text { Thickness } \\
\text { (mils) }\end{array}$ & ID \\
\hline North & Butyl & 15 & NB15 & North & Butyl & 30 & NB30 \\
\hline Piercan & Butyl & 15 & PB15 & Piercan & Butyl & 30 & PB30 \\
\hline Piercan & $\begin{array}{l}\text { Electrostatic } \\
\text { Discharge } \\
\text { Butyl }\end{array}$ & 15 & PESDB15 & Piercan & $\begin{array}{l}\text { Electrostatic } \\
\text { Discharge } \\
\text { Butyl }\end{array}$ & 24 & PESDB24 \\
\hline Guardian & Butyl & 15 & GB15 & Guardian & Butyl & 30 & GB30 \\
\hline Jung & $\begin{array}{l}\text { Butyl- } \\
\text { Hypalon }\end{array}$ & 27 & $\mathrm{JBH} 27$ & Jung & Butyl-Viton ${ }^{\circ}$ & 20 & JBV20 \\
\hline Jung & Viton & 24 & JV24 & Jung & Viton & 31 & JV31 \\
\hline Piercan & Polyurethane & 15 & PU15 & Piercan & $\begin{array}{l}\text { Polyurethane- } \\
\text { Hypalon }\end{array}$ & 20 & PUY20 \\
\hline
\end{tabular}




\section{Experiment}

ASTM D412 (1) was used as a guideline for this experiment. Three "dog bone" shaped tensile samples were cut along the sleeve axis from each glove represented. Two sample sizes were used (Figure 1). The longer gauge length sample was used for the majority of the tests, but two glove compounds required the use of a shorter test sample. The die geometry and select dimensions are shown in Figure 1 . The glove material was placed on a piece of Teflon and cut with a die with the aid of a manual press. The samples were pulled to failure with an Instron Model 4507 test machine including a MTS Systems Renew Package at a constant crosshead rate of 20 inches/ minute. The elongation of each sample was assumed to be the applied elongation of the crosshead (no independent elongation gages were used.) The loads, percent elongation and peak stress were recorded on a computer using Testworks software. A $200 \mathrm{lb}$ capacity load cell calibrated to ASTM E4 (2) was used during this experiment.

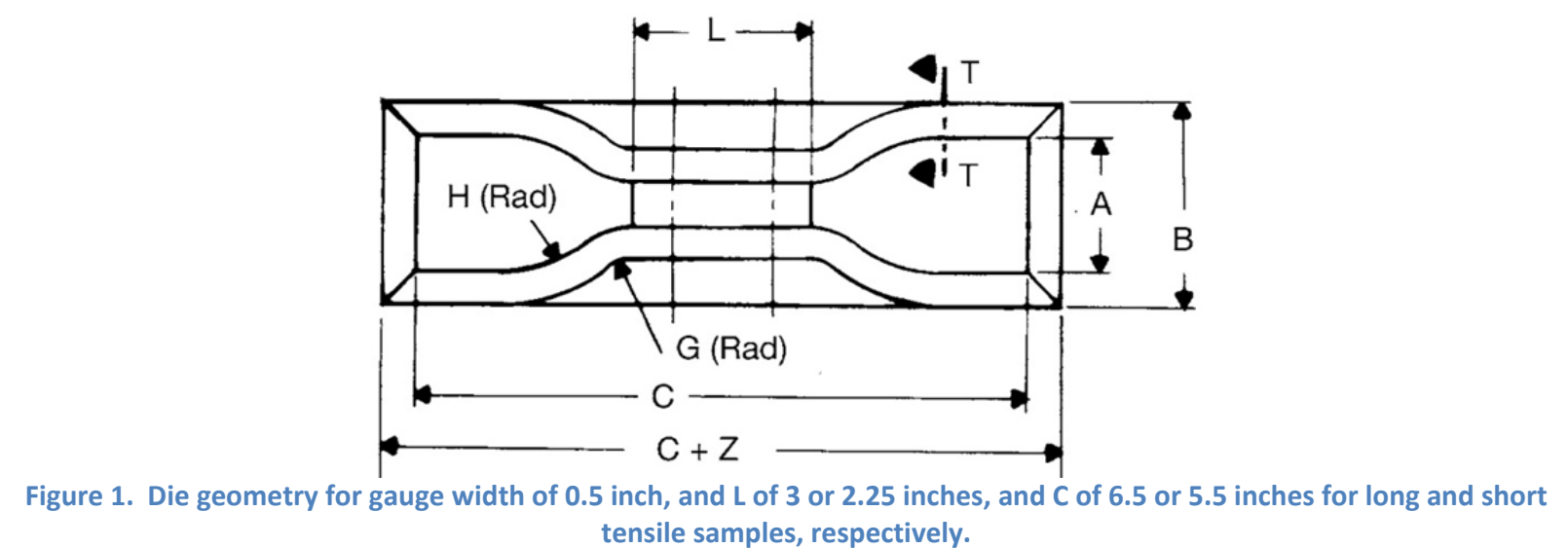

\section{Results}

\section{Butyl}

Typical load-elongation and stress-strain curves are shown in Figures 2 and 3 for 15 mil North Butyl rubber gloves. Note that the load increases with increased time, Figure 2, in a nonlinear manner. Figure 3 shows the results from three tests- the data from separate tests of the same material were quite consistent; this was observed for all of the gloves tested, including the alternatives to pure butyl. The average stress, elongation, and load at failure are presented in Table 2 and the results from the individual tests are tabulated in Appendix A and shown graphically in Appendix B. 


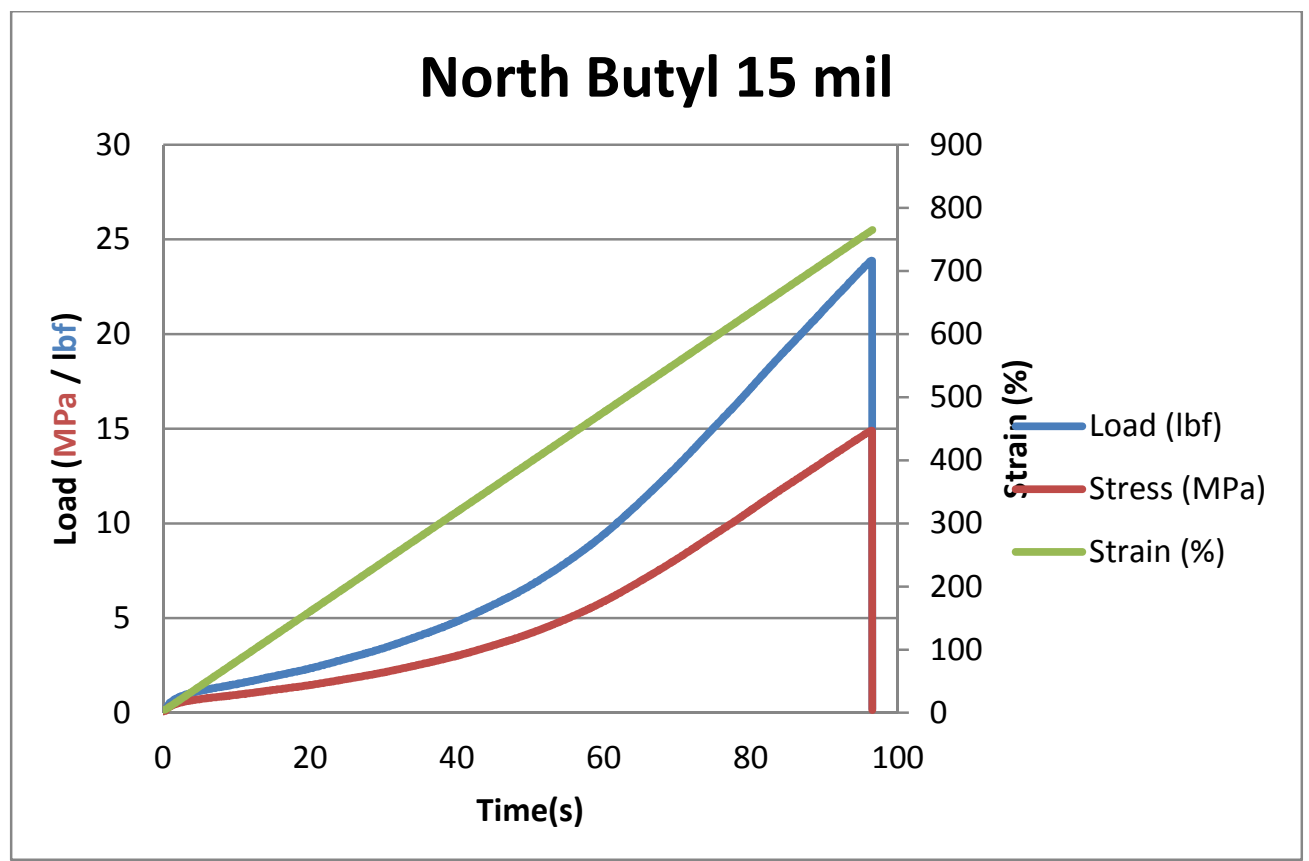

Figure 2. Typical load (lbf), stress (MPa), and strain (\%) results for North butyl rubber glove material.

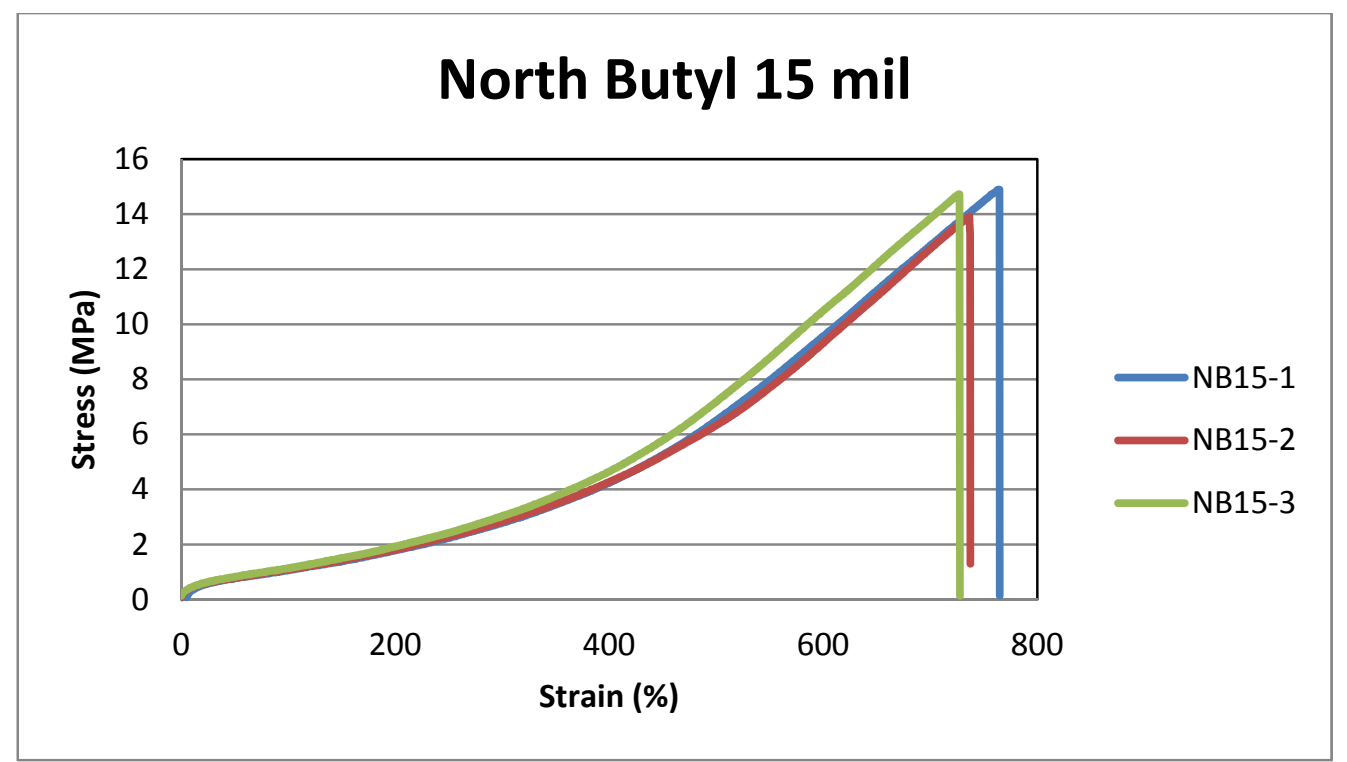

Figure 3. Stress (MPa) versus strain (\%) results for three North Butyl rubber gloves.

Table 2. Butyl rubber glove results.

\begin{tabular}{|l|c|c|c|c|c|c|c|c|}
\hline & $\begin{array}{c}\text { GB15 } \\
\text { Ave. }\end{array}$ & $\begin{array}{c}\text { GB30 } \\
\text { Ave. }\end{array}$ & $\begin{array}{c}\text { NB15 } \\
\text { Ave. }\end{array}$ & $\begin{array}{c}\text { NB30 } \\
\text { Ave. }\end{array}$ & $\begin{array}{c}\text { PB15 } \\
\text { Ave. }\end{array}$ & $\begin{array}{c}\text { PB30 } \\
\text { Ave. }\end{array}$ & $\begin{array}{c}\text { PESDB15 } \\
\text { Ave. }\end{array}$ & $\begin{array}{c}\text { PESDB24 } \\
\text { Ave. }\end{array}$ \\
\hline $\begin{array}{l}\text { Stress } \\
\text { (Mpa) }\end{array}$ & 11 & 12 & 15 & 13 & 11 & 11 & 13 & 13 \\
\hline \% Elong & 666 & 726 & 745 & 754 & 714 & 843 & 680 & 746 \\
\hline Load (lbf) & 16 & 27 & 23 & 31 & 15 & 27 & 14 & 19 \\
\hline $\begin{array}{l}\text { Thickness } \\
\text { (in) }\end{array}$ & 0.020 & 0.029 & 0.021 & 0.034 & 0.019 & 0.032 & 0.015 & 0.020 \\
\hline
\end{tabular}


These tensile strength (TS) results indicate some scatter for the strength of the butyl rubber gloves but the tensile strength is bounded by 11 to $15 \mathrm{MPa}$ with tensile elongations from 666 to $843 \%$. The determination of the tensile strength, which can be modified by additives, is an important material property, but the load at failure is more applicable information for the product and application within the facility. The failure load is also listed in Table 2 and shown in Figure 3. These data show that the increased thickness results in an increased load for failure, as expected.

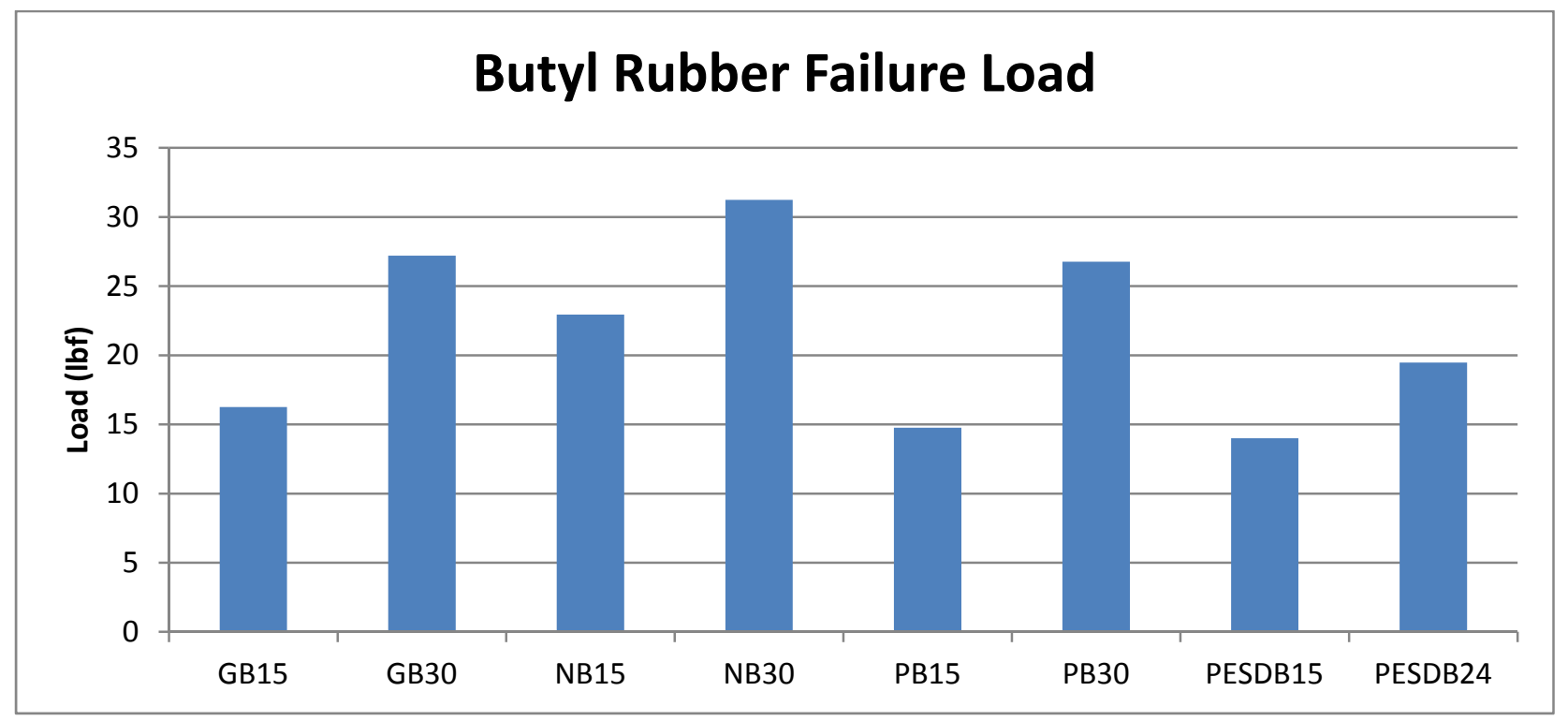

Figure 4. Comparison of tensile load of Butyl rubber gloves.

\section{Other Compound Gloves}

The tensile properties of gloves made from compounds other than butyl are listed in Table 3 . These data indicate a wider range of tensile strength from 5.4 MPa to $49 \mathrm{MPa}$. The Viton glove exhibits the lowest strength at 5.4 MPA for a 31 mil thick glove, the butyl-Hypalon , butyl-Viton , and 24 mil Viton are second lowest with about $8 \mathrm{MPa}$, with Hypalon ${ }^{\circ}(19 \mathrm{MPa}$ ), Hypalon -Polyurethane (24 MPa) and Polyurethane (49 $\mathrm{MPa}$ ) completing the rankings. These strengths are both considerably weaker $\sim 1 / 3 \mathrm{TS}$ of Butyl to considerably stronger 3X Butyl.

The load at failure is indicated in Table 3 and Figure 4. The polyurethane and Hypalon indicate a significant increase in load at failure compared to Butyl of comparable thickness. This result is expected since polyurethane is considered to be tougher than butyl. The Viton exhibits interesting results. The JV24 and JV31 have thicknesses that vary between $0.025^{\prime \prime}$ and 0.039 " yet exhibit virtually identical failure loads of 14 and $15 \mathrm{MPa}$, respectively. A different effect is also apparent from the tensile strength which shows a reduced \% elongation value for the thicker gloves compared to the thinner ones. 
Table 3. Tensile properties of other glove compositions.

\begin{tabular}{|l|c|c|c|c|c|c|c|}
\hline & $\begin{array}{c}\text { JBH27 } \\
\text { Ave. }\end{array}$ & $\begin{array}{c}\text { JBV20 } \\
\text { Ave. }\end{array}$ & $\begin{array}{c}\text { JV24 } \\
\text { Ave. }\end{array}$ & $\begin{array}{c}\text { JV31 } \\
\text { Ave. }\end{array}$ & $\begin{array}{c}\text { PU15 } \\
\text { Ave. }\end{array}$ & $\begin{array}{c}\text { PUY20 } \\
\text { Ave. }\end{array}$ & $\begin{array}{l}\text { PY25 } \\
\text { Ave. }\end{array}$ \\
\hline $\begin{array}{l}\text { Stress } \\
\text { (MPa) }\end{array}$ & 7.8 & 8.0 & 7.6 & 5.4 & 49 & 24 & 19 \\
\hline$\%$ Elong & 454 & 640 & 545 & 453 & 697 & 603 & 570 \\
\hline Load (Ibf) & 16 & 10 & 14 & 15 & 55 & 37 & 30 \\
\hline $\begin{array}{l}\text { Thickness } \\
\text { (in) }\end{array}$ & 0.045 & 0.017 & 0.025 & 0.039 & 0.015 & 0.022 & 0.021 \\
\hline
\end{tabular}

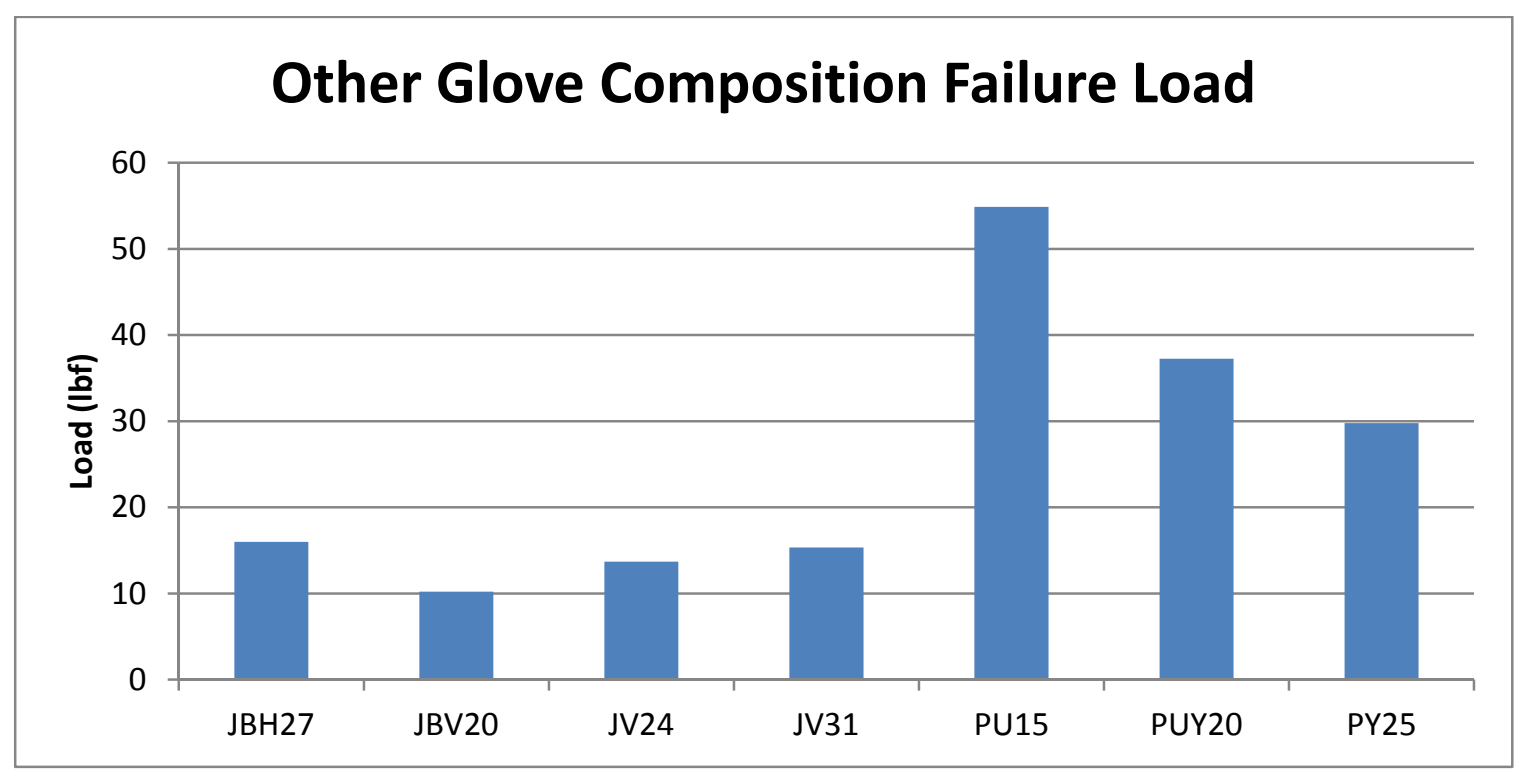

Figure 5. Comparison of load at failure of other glove compositions

Table 4. Property requirements for selected gloves (3).

\begin{tabular}{|l|l|l|}
\hline Material & $\begin{array}{l}\text { Min Tensile Strength } \\
(\mathrm{psi}) /(\mathrm{MPa})\end{array}$ & Min Ultimate Elongation (\%) \\
\hline Butyl (B) & $1300 / 9.1$ & 550 \\
\hline $\begin{array}{l}\text { CSM (Chlorosulfonated } \\
\text { Polyethylene (Y)) - Hypalon }\end{array}$ & $1900 / 13$. & 500 \\
\hline Polyurethane / CSM (UY) & $3500 / 24$. & \\
20 mil & $2500 / 17$. & 450 \\
12 mil & $5000 / 34$. & 450 \\
\hline Polyurethane & 400 \\
\hline
\end{tabular}

Note: No mechanical property data is provided for Viton ${ }^{\circ}$ based gloves. Literature (4) indicates 5002000 psi capability (3.4-14 MPa) at 400-500\% elongation. 


\section{Summary and Conclusions}

The glove box glove specification (3) for Savannah River Site (SRS) requires the above properties listed in Table 4 for the gloves included in this study. All of the Butyl gloves meet the requirements of the specification for both tensile strength and elongation. The listed gloves, $U, U Y$, and $Y$ meet the minimum requirements for both tensile strength and elongation, with the PUY just meeting tensile strength minima. Since there are no SRS requirements for Viton containing gloves these are reported for information only; however, the Jung manufactured gloves exhibited the lowest tensile strengths of the materials tested, with tensile strengths as low as $5.4 \mathrm{MPa}$, and commonly $8 \mathrm{MPa}$.

The Piercan Polyurethane gloves were the strongest material tested. They exhibited the highest tensile strength, well over minimum tensile elongation, and the highest load to failure. They were also one of the thinnest gloves tested which may offer improved tactile response.

\section{Acknowledgements}

The authors would like to thank Tritium Operations, Tritium Engineering, and Tritium Extraction Facility for technical and financial support.

\section{References}

1. ASTM D412-06, Standard Test Methods for Vulcanized Rubber and Thermoplastic ElastomersTension, West Conshohocken, PA 19428, 2006.

2. ASTM E4-10, Standard Practices for Force Verification of Testing Machines, West Conshohocken, PA 19428, 2010.

3. SRS Glove Specification, "Gloves for Gloveboxes (U), March 2011.

4. http://www.robinsonrubber.com/pdfs/FKMRubber.pdf, 2005 
Appendix A: Raw Data

\begin{tabular}{|l|r|r|r|r|r|r|r|r|}
\hline & GB15-1 & GB15-2 & GB15-3 & GB15 Ave. & GB30-1 & GB30-2 & GB30-3 & GB30 Ave. \\
\hline Time & 82 & 85 & 85 & 84 & 94 & 91 & 101 & 95 \\
\hline Load & 15 & 17 & 17 & 16 & 31 & 25 & 26 & 27 \\
\hline Stress & 11 & 11.0 & 11 & 11 & 12 & 12 & 12 & 12 \\
\hline \% Elong & 641 & 686 & 670 & 666 & 705 & 721 & 752 & 726 \\
\hline Thickness (in) & 0.020 & 0.020 & 0.020 & 0.020 & 0.030 & 0.029 & 0.029 & 0.029 \\
\hline Width (in) & 0.501 & 0.504 & 0.505 & 0.503 & 0.506 & 0.505 & 0.507 & 0.506 \\
\hline
\end{tabular}

\begin{tabular}{|l|r|r|r|r|r|r|r|r|r|}
\hline & NB15-1 & NB15-2 & NB15-3 & NB15 Ave. & NB30-1 & NB30-4 & NB30-5 & NB30-6 & NB30 Ave. \\
\hline Time & 97 & 96 & 98 & 97 & 109 & 81 & 81 & 78 & 87 \\
\hline Load & 24 & 22 & 23 & 23 & 38 & 30 & 30 & 28 & 31 \\
\hline Stress & 15 & 14 & 15 & 15 & 15 & 12 & 12 & 12 & 13 \\
\hline \% Elong & 765 & 743 & 726 & 745 & 831 & 707 & 721 & 758 & 754 \\
\hline Thickness (in) & 0.022 & 0.022 & 0.021 & 0.021 & 0.034 & 0.034 & 0.034 & 0.033 & 0.034 \\
\hline Width (in) & 0.514 & 0.510 & 0.508 & 0.511 & 0.502 & 0.503 & 0.505 & 0.500 & 0.503 \\
\hline
\end{tabular}

\begin{tabular}{|l|r|r|r|r|r|r|r|r|r|}
\hline & PB15-4 & PB15-5 & PB15-6 & PB15-7 & PB15 Ave. & PB30-1 & PB30-2 & PB30-3 & PB30 Ave. \\
\hline Time & 99 & 96 & 88 & 74 & 89 & 103 & 101 & 101 & 102 \\
\hline Load & 17 & 16 & 13 & 13 & 15 & 27 & 26 & 28 & 27 \\
\hline Stress & 12 & 11 & 10 & 9.4 & 11 & 11 & 11 & 11 & 11 \\
\hline \% Elong & 781 & 734 & 668 & 674 & 714 & 868 & 820 & 839 & 843 \\
\hline Thickness (in) & 0.019 & 0.019 & 0.018 & 0.019 & 0.019 & 0.033 & 0.031 & 0.033 & 0.032 \\
\hline Width (in) & 0.505 & 0.505 & 0.505 & 0.505 & 0.505 & 0.502 & 0.509 & 0.509 & 0.507 \\
\hline
\end{tabular}

${ }_{1}^{1}$ The long samples did not reach failure so the smaller samples were tested, Figure 1. Small samples tended to fail at transition rather than center of reduced section. 


\begin{tabular}{|l|r|r|r|r|r|r|r|r|}
\hline & PESDB15-1 & PESDB15-2 & PESDB15-3 & PESDB15 Ave. & PESDB24-1 & PESDB24-2 & PESDB24-3 & PESDB24 Ave. \\
\hline Time & 90 & 86 & 92 & 89 & 98 & 92 & 97 & 95 \\
\hline Load & 14 & 14 & 14 & 14 & 20 & 19 & 20 & 19 \\
\hline Stress & 12 & 13 & 13 & 13 & 13 & 13 & 14 & 13 \\
\hline \% Elong & 711 & 673 & 655 & 680 & 747 & 714 & 778 & 746 \\
\hline Thickness (in) & 0.015 & 0.015 & 0.015 & 0.015 & 0.020 & 0.020 & 0.019 & 0.020 \\
\hline Width (in) & 0.507 & 0.507 & 0.505 & 0.506 & 0.505 & 0.512 & 0.509 & 0.509 \\
\hline
\end{tabular}

\begin{tabular}{|l|r|r|r|r|r|r|r|r|}
\hline & \multicolumn{1}{|l|}{ JBH27-1 } & \multicolumn{1}{l|}{ JBH27-2 } & \multicolumn{1}{l|}{ JBH27-3 } & \multicolumn{1}{l|}{ JBH27 Ave. } & JBV20-1 & JBV20-2 & \multicolumn{1}{l|}{ JBV20-3 } & JBV20 Ave. \\
\hline Time & 57 & 56 & 56 & 56 & 83 & 80 & 82 & 82 \\
\hline Load & 16 & 16 & 16 & 16 & 10 & 10 & 10 & 10 \\
\hline Stress & 7.9 & 7.8 & 7.8 & 7.8 & 8.0 & 8.1 & 7.9 & 8.0 \\
\hline \% Elong & 454 & 458 & 451 & 454 & 634 & 643 & 643 & 640 \\
\hline Thickness (in) & 0.028 & 0.028 & 0.080 & 0.045 & 0.017 & 0.017 & 0.018 & 0.017 \\
\hline Width (in) & 0.506 & 0.504 & 0.503 & 0.504 & 0.510 & 0.503 & 0.505 & 0.506 \\
\hline
\end{tabular}

\begin{tabular}{|l|r|r|r|r|r|r|r|r|}
\hline & JV24-1 & \multicolumn{1}{|l}{ JV24-2 } & JV24-3 & JV24 Ave. & JV31-1 & JV31-2 & JV31-3 & JV31 Ave. \\
\hline Time & 71 & 66 & 71 & 70 & 63 & 56 & 56 & 58 \\
\hline Load & 14 & 13 & 14 & 14 & 16 & 15 & 15 & 15 \\
\hline Stress & 7.8 & 7.3 & 7.7 & 7.6 & 5.8 & 5.1 & 5.2 & 5.4 \\
\hline \% Elong & 559 & 534 & 541 & 545 & 494 & 443 & 423 & 453 \\
\hline Thickness (in) & 0.025 & 0.025 & 0.025 & 0.025 & 0.039 & 0.040 & 0.039 & 0.039 \\
\hline Width (in) & 0.510 & 0.505 & 0.506 & 0.507 & 0.504 & 0.505 & 0.506 & 0.505 \\
\hline
\end{tabular}




\begin{tabular}{|l|r|r|r|r|r|r|r|r|}
\hline & PU15-1 & PU15-2 & PU15-3 & PU15 Ave. & PUY20-1 & PUY20-2 & PUY20-3 & PUY20 Ave. \\
\hline Time & 87 & 87 & 93 & 89 & 77 & 77 & 77 & 77 \\
\hline Load & 53 & 55 & 57 & 55 & 38 & 37 & 37 & 37 \\
\hline Stress & 47 & 50 & 51 & 49 & 24 & 24 & 22 & 24 \\
\hline \% Elong & 674 & 696 & 722 & 697 & 595 & 625 & 588 & 603 \\
\hline Thickness (in) & 0.015 & 0.015 & 0.015 & 0.015 & 0.021 & 0.021 & 0.023 & 0.022 \\
\hline Width (in) & 0.505 & 0.505 & 0.515 & 0.508 & 0.504 & 0.508 & 0.510 & 0.507 \\
\hline
\end{tabular}

\begin{tabular}{|l|r|r|r|r|}
\hline & \multicolumn{1}{|l|}{ PY25-1 } & \multicolumn{1}{l|}{ PY25-2 } & PY25-3 & PY25 Ave. \\
\hline Time & 72 & 74 & 72 & 73 \\
\hline Load & 31 & 31 & 27 & 30 \\
\hline Stress & 20 & 20 & 18 & 19 \\
\hline \% Elong & 568 & 577 & 564 & 570 \\
\hline Thickness (in) & 0.022 & 0.021 & 0.021 & 0.021 \\
\hline Width (in) & 0.505 & 0.506 & 0.504 & 0.505 \\
\hline
\end{tabular}


Appendix B: Tensile Charts

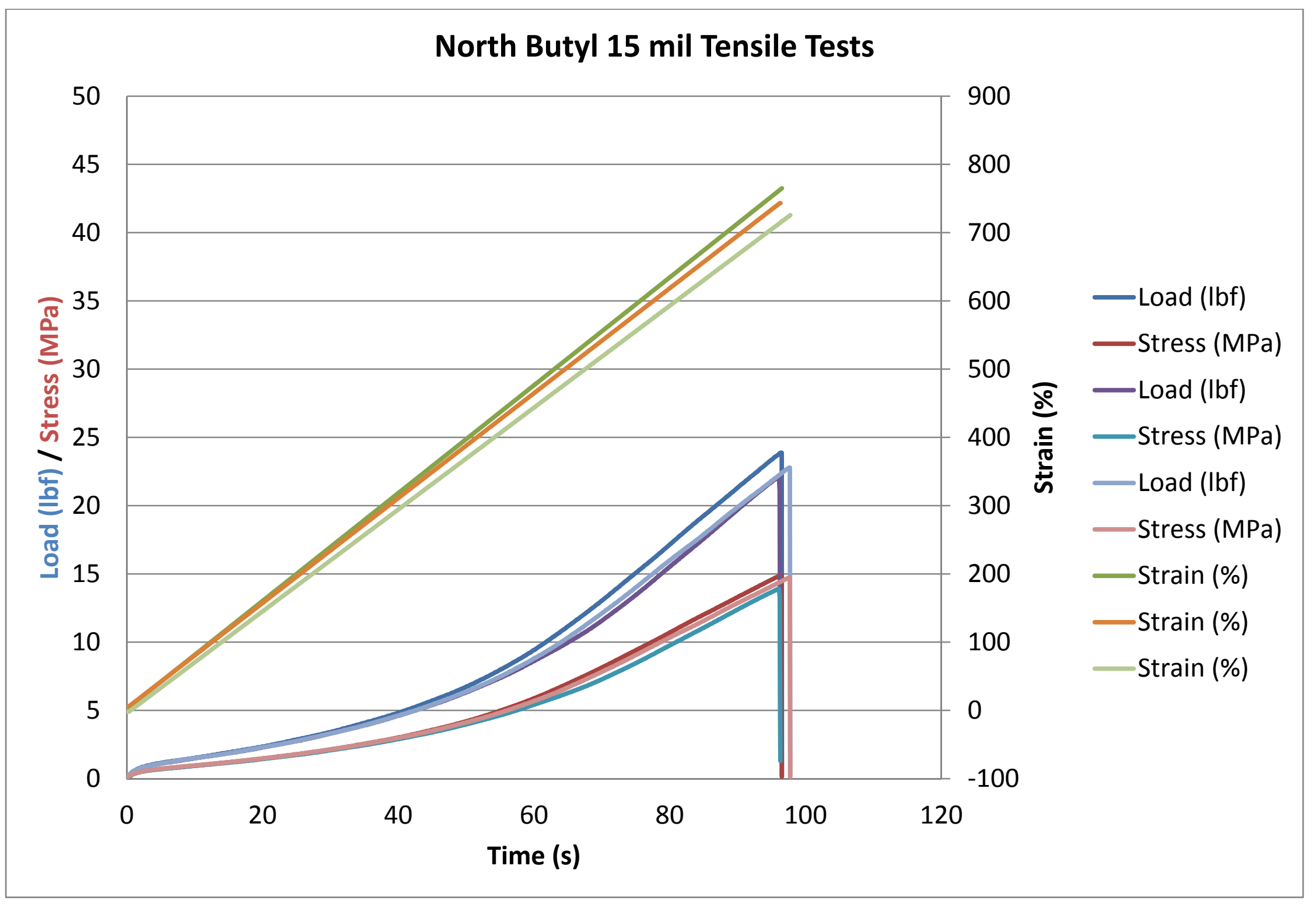




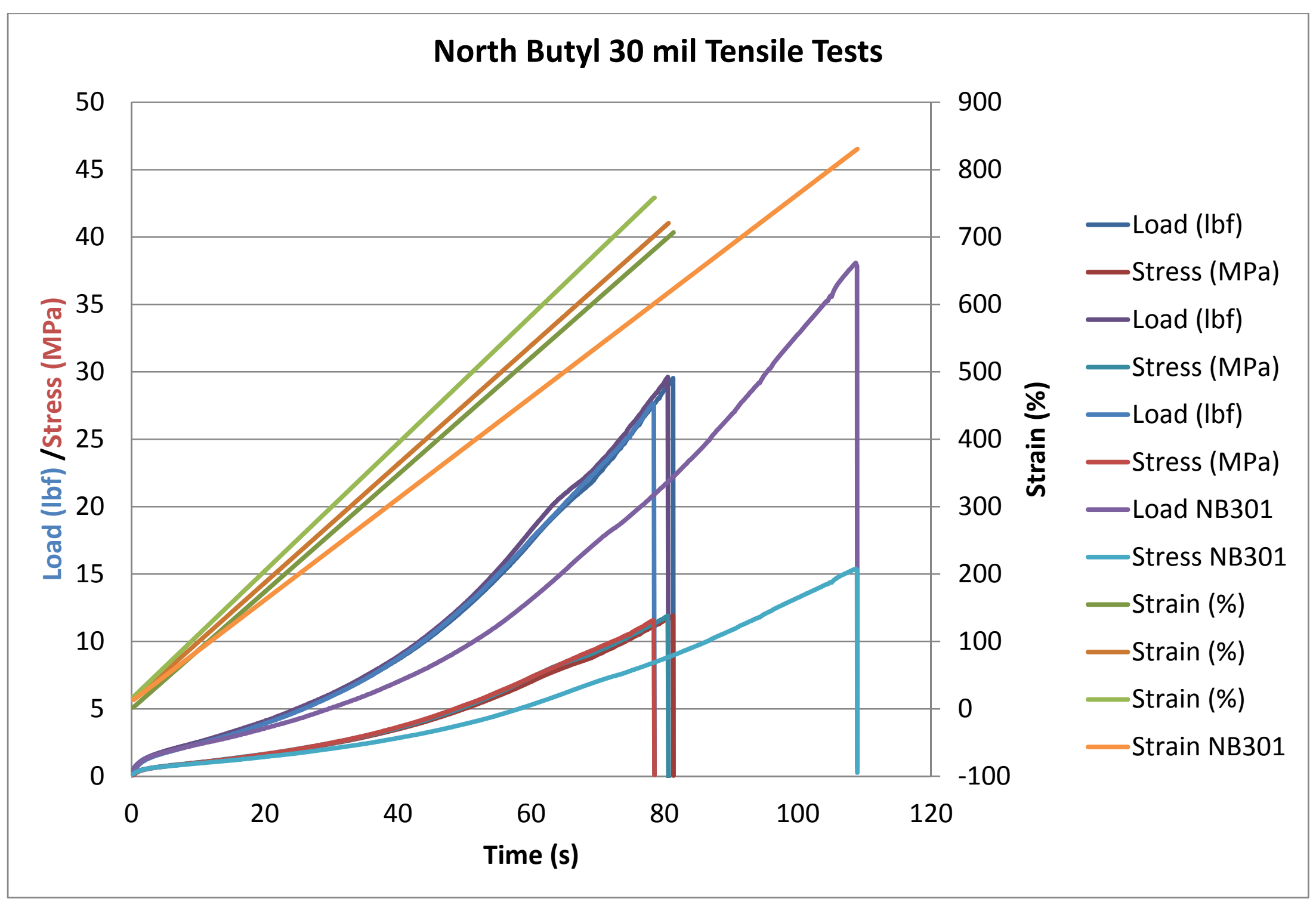




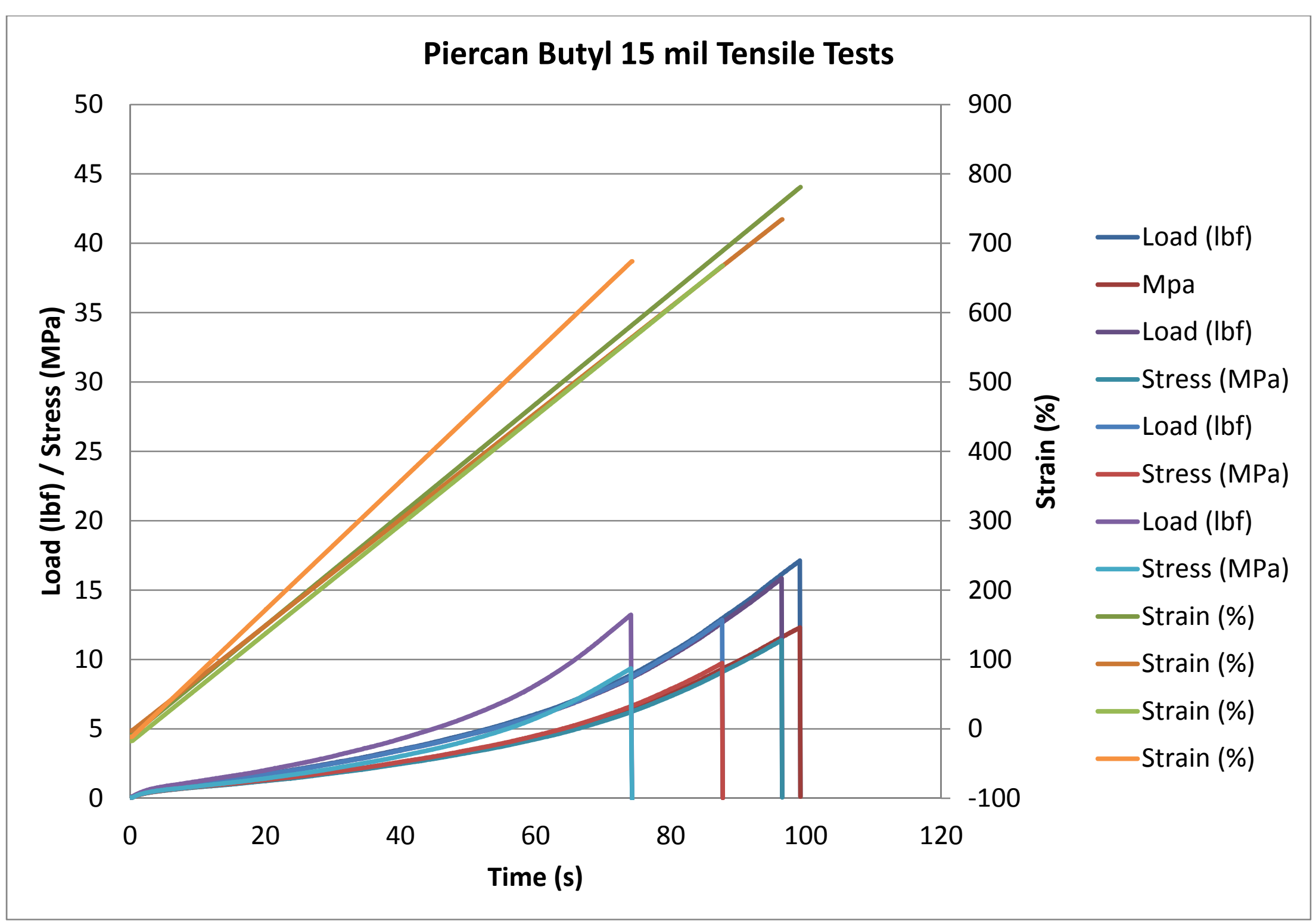




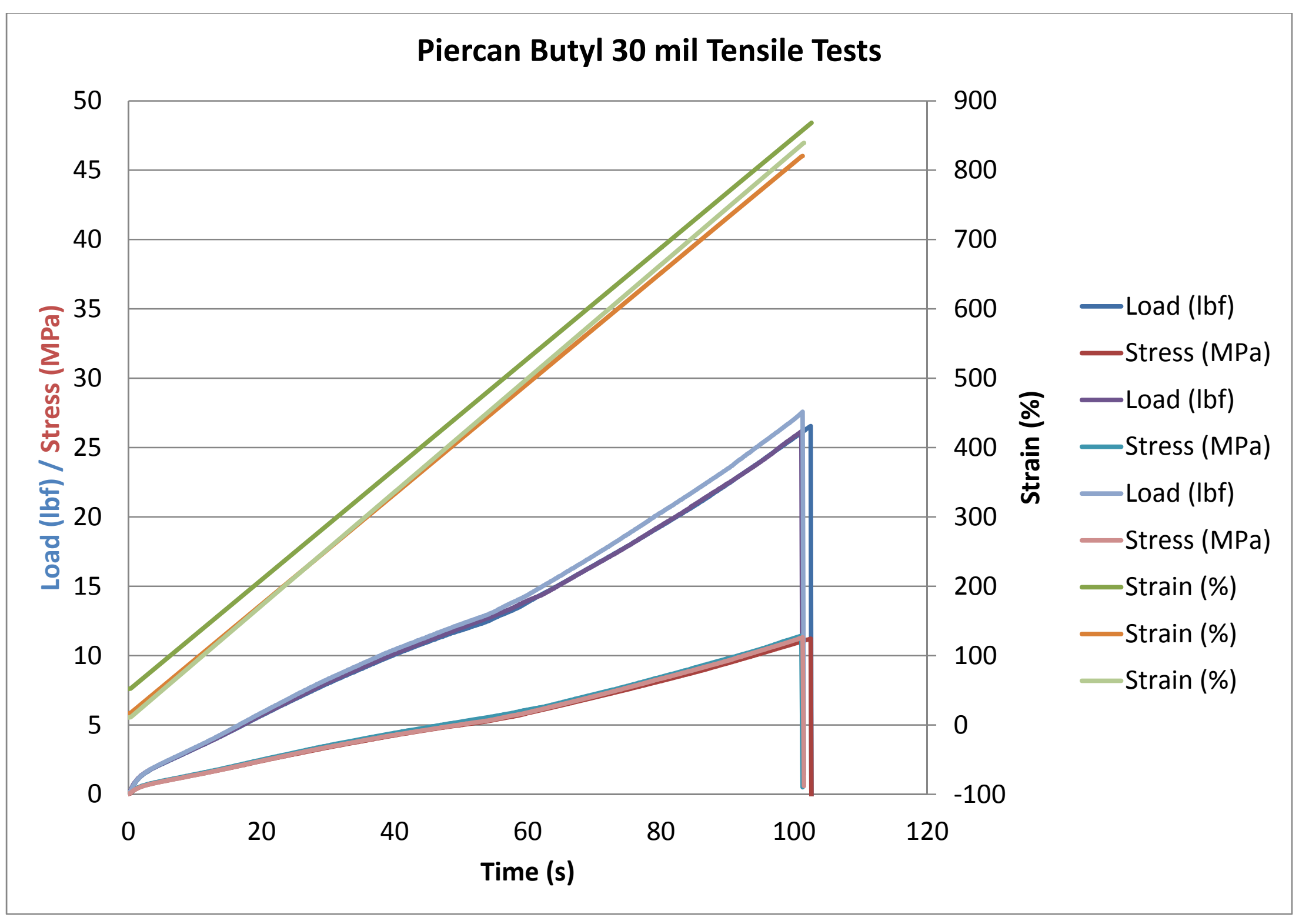




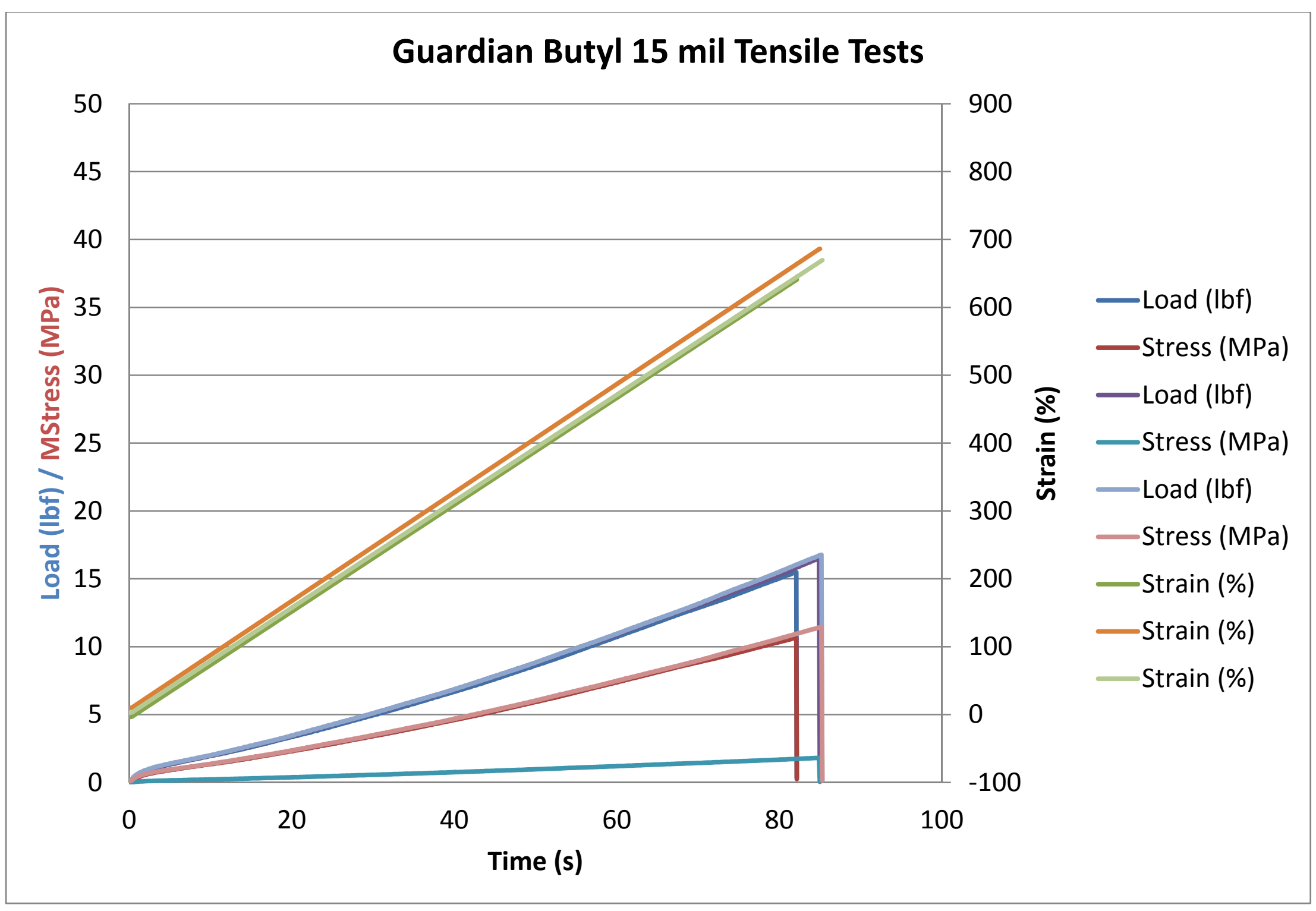




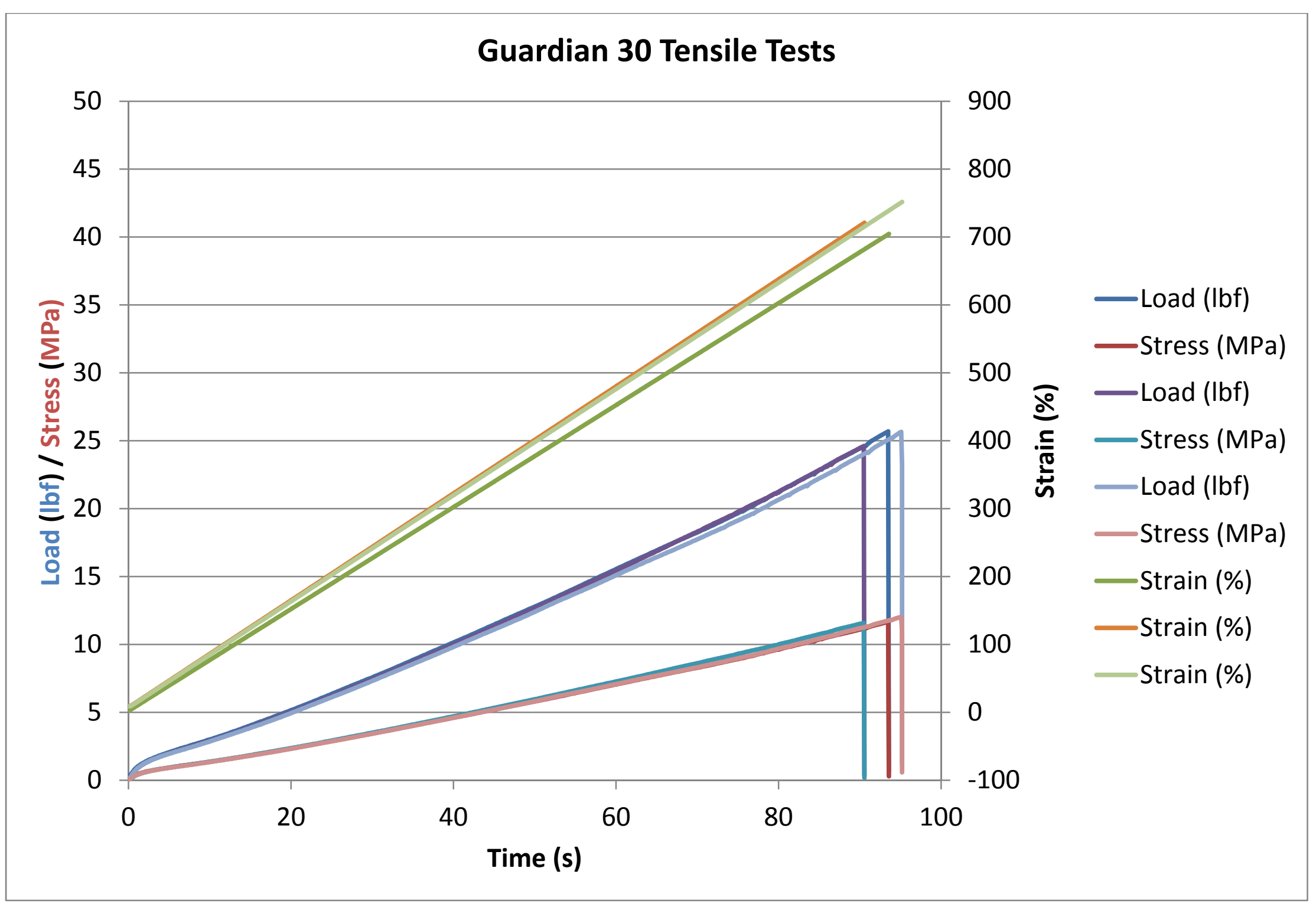




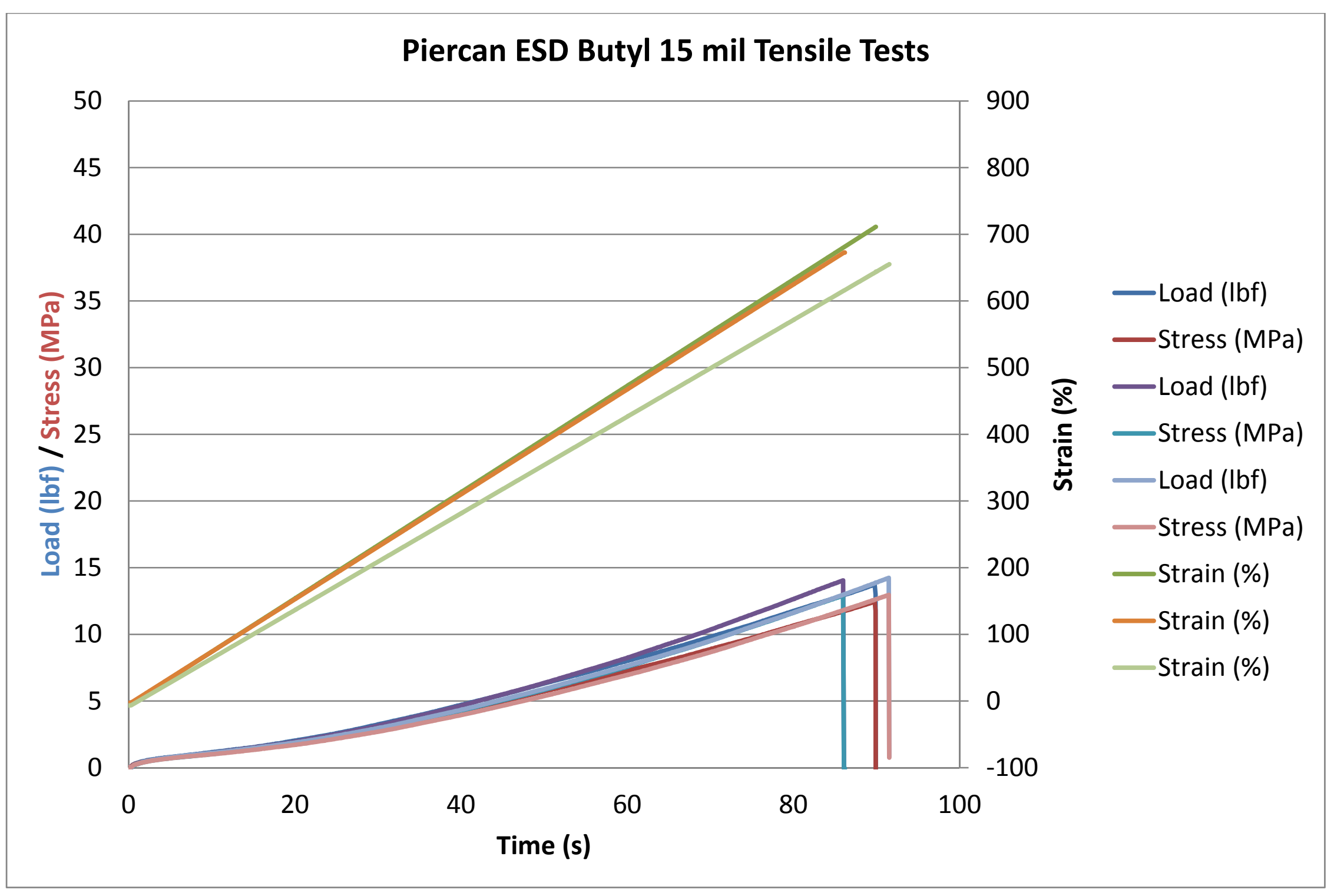




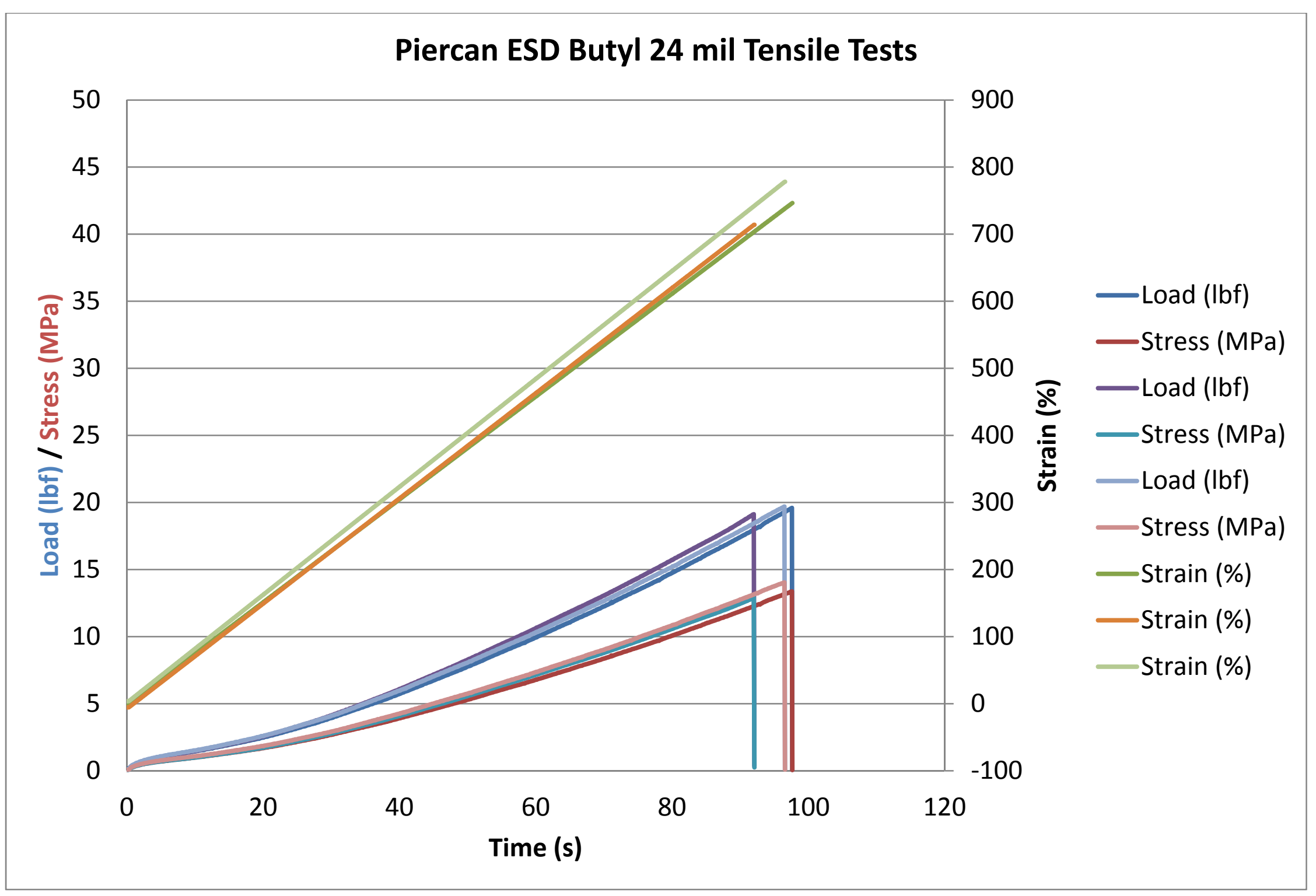




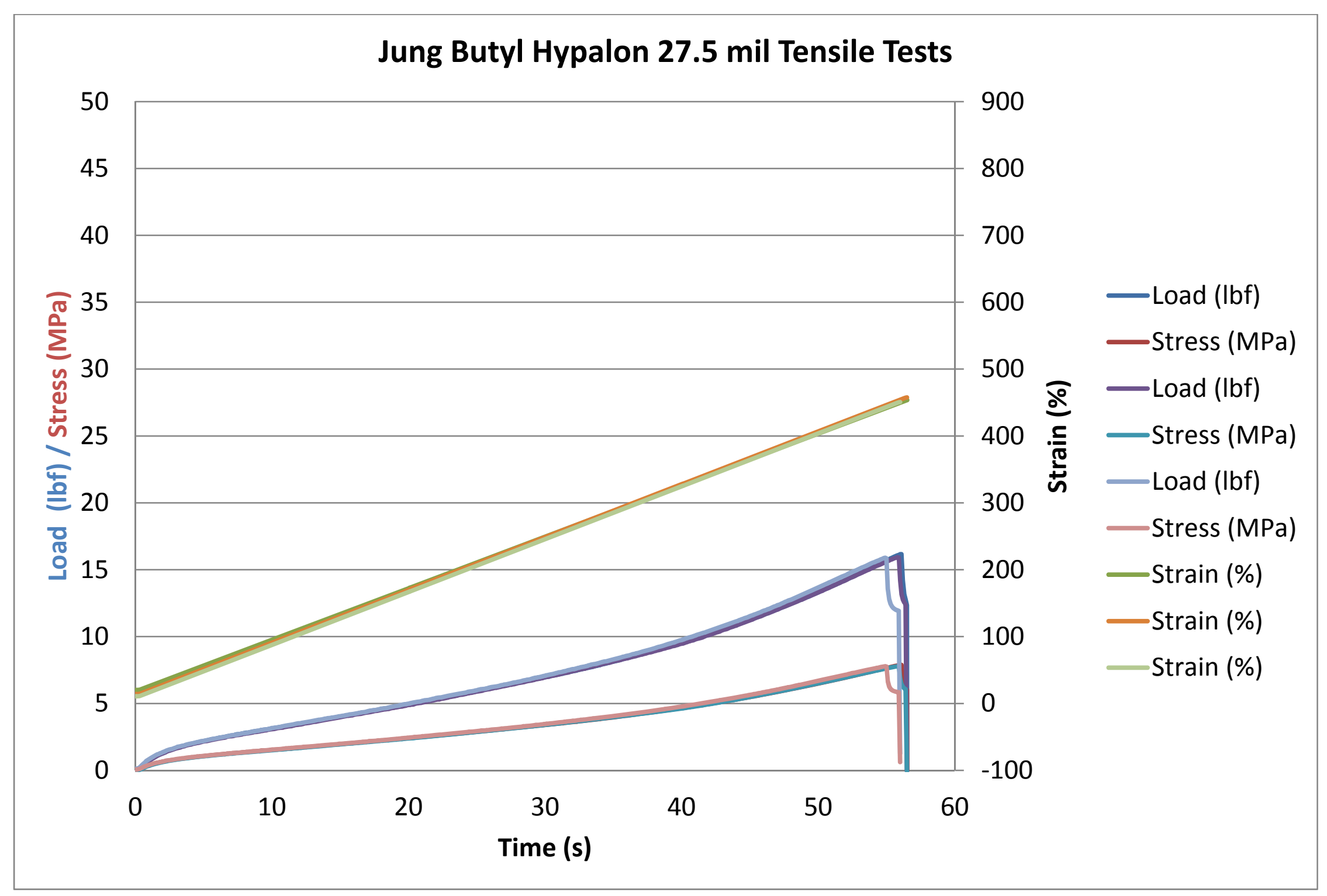




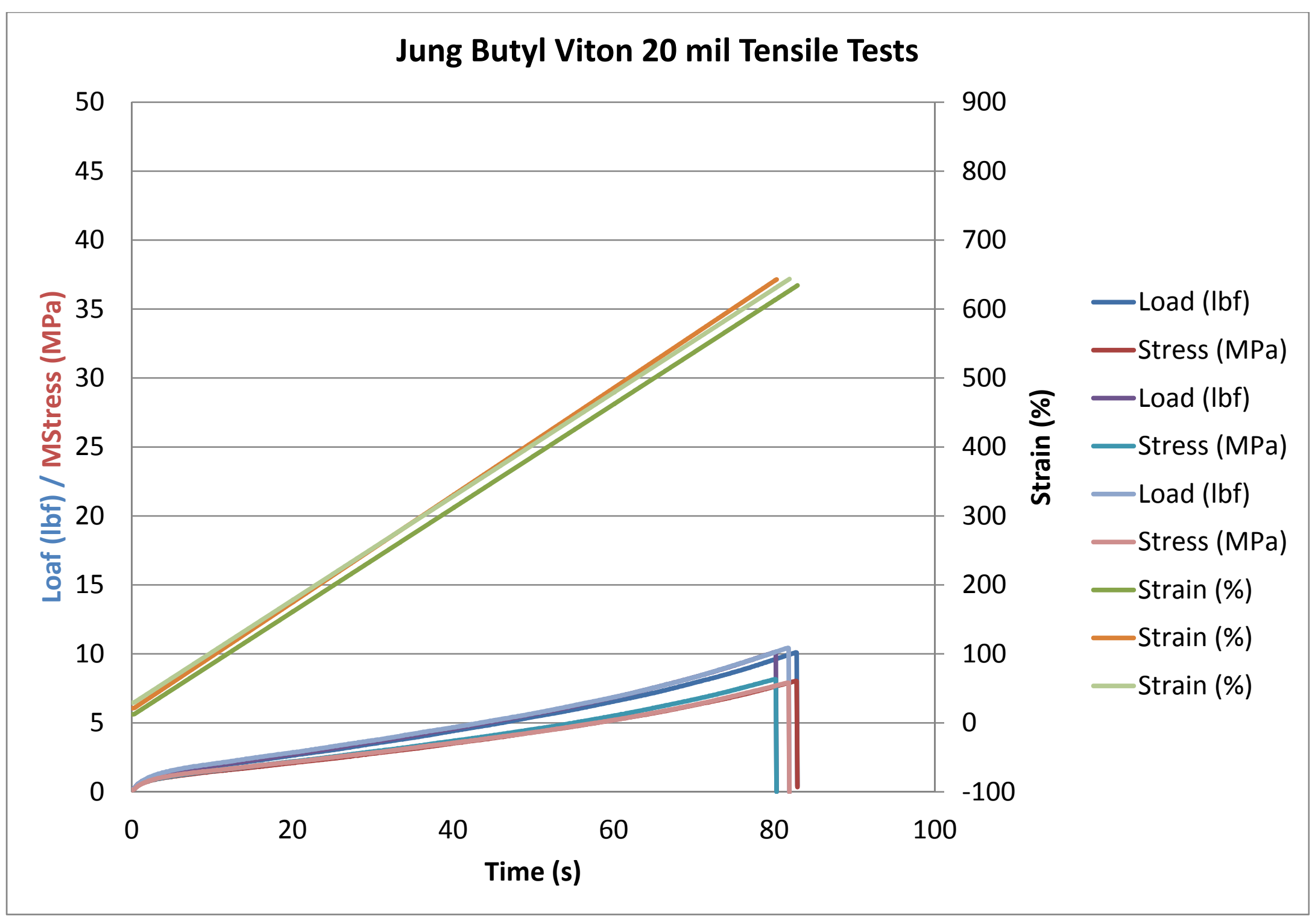




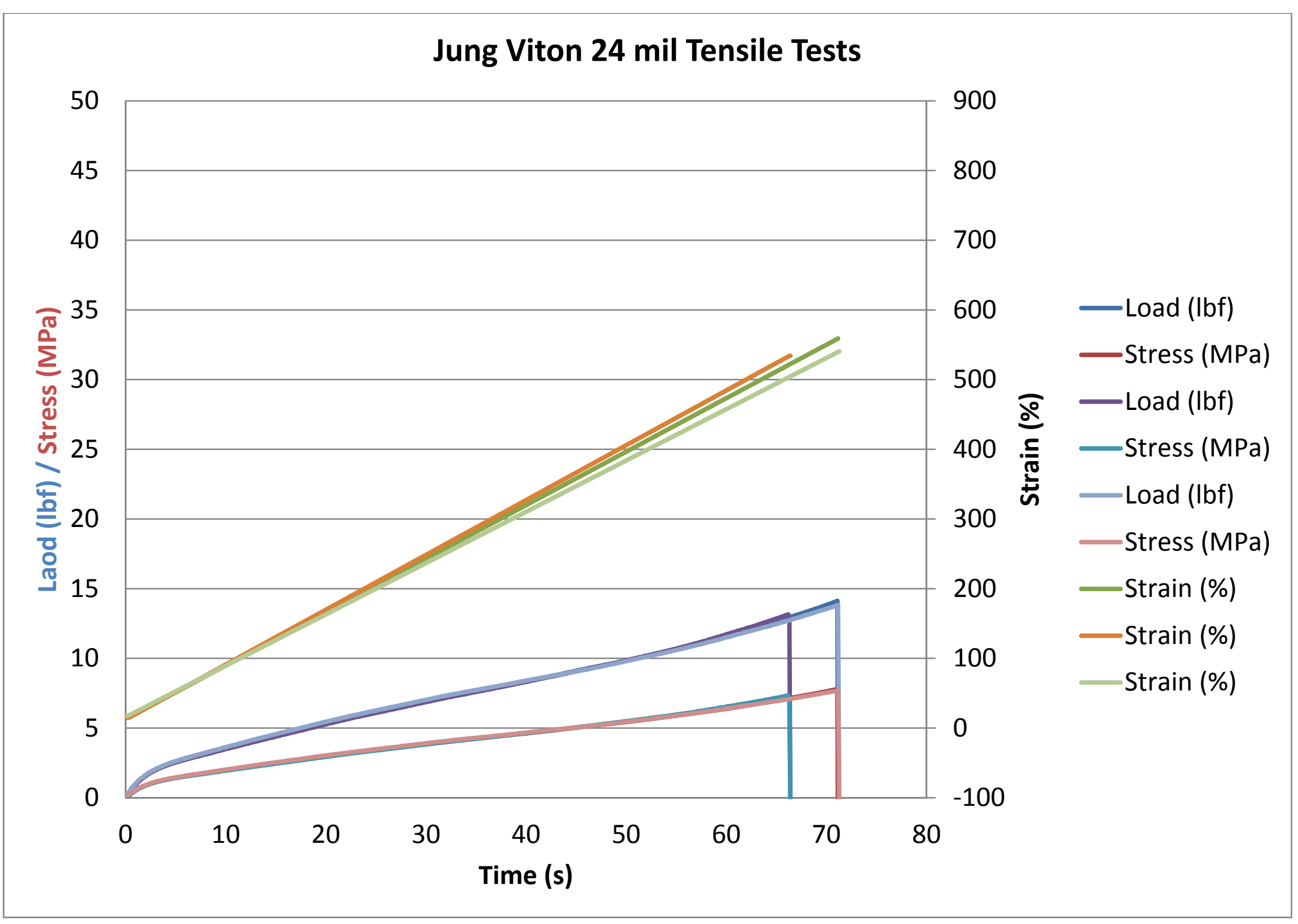




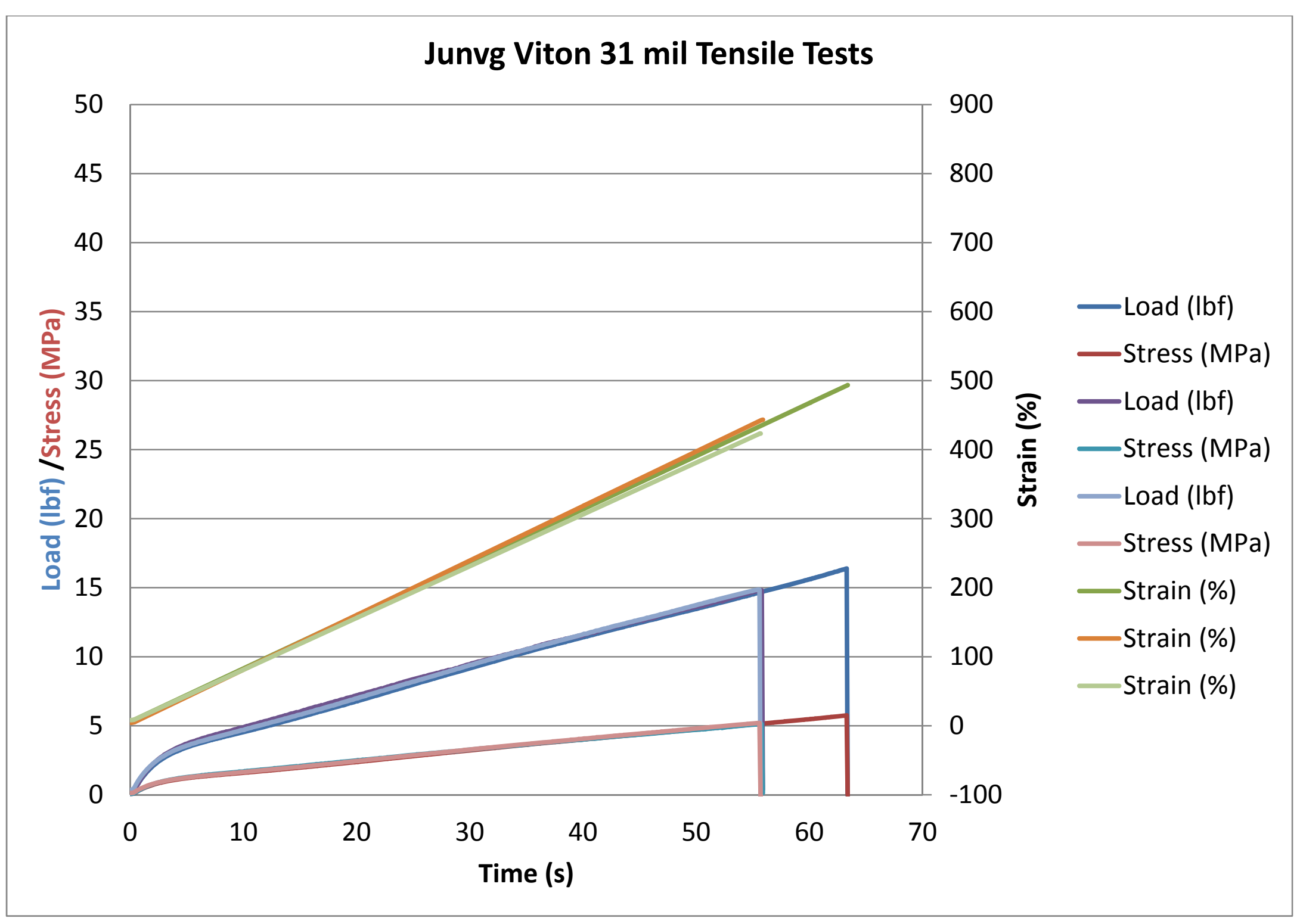




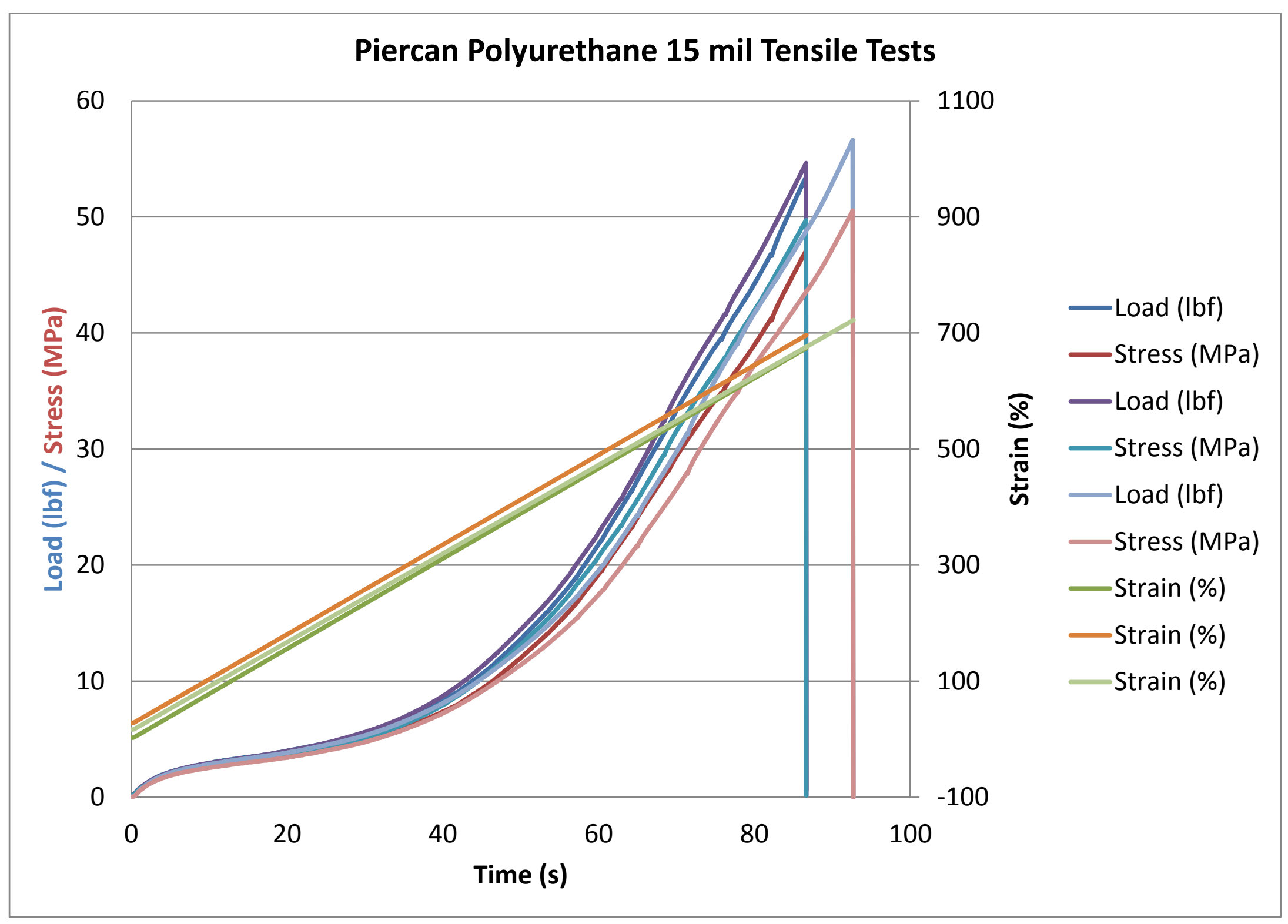




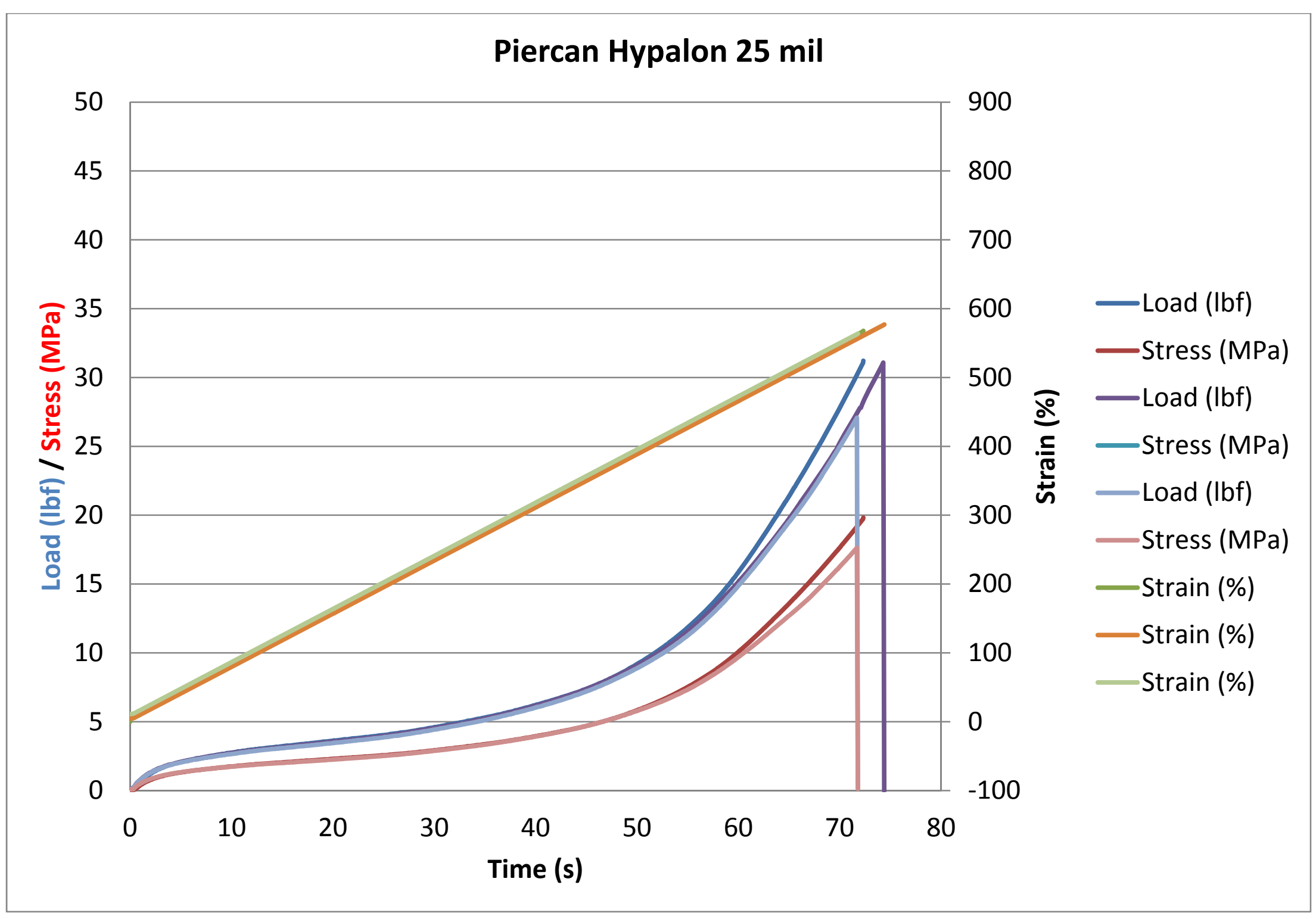




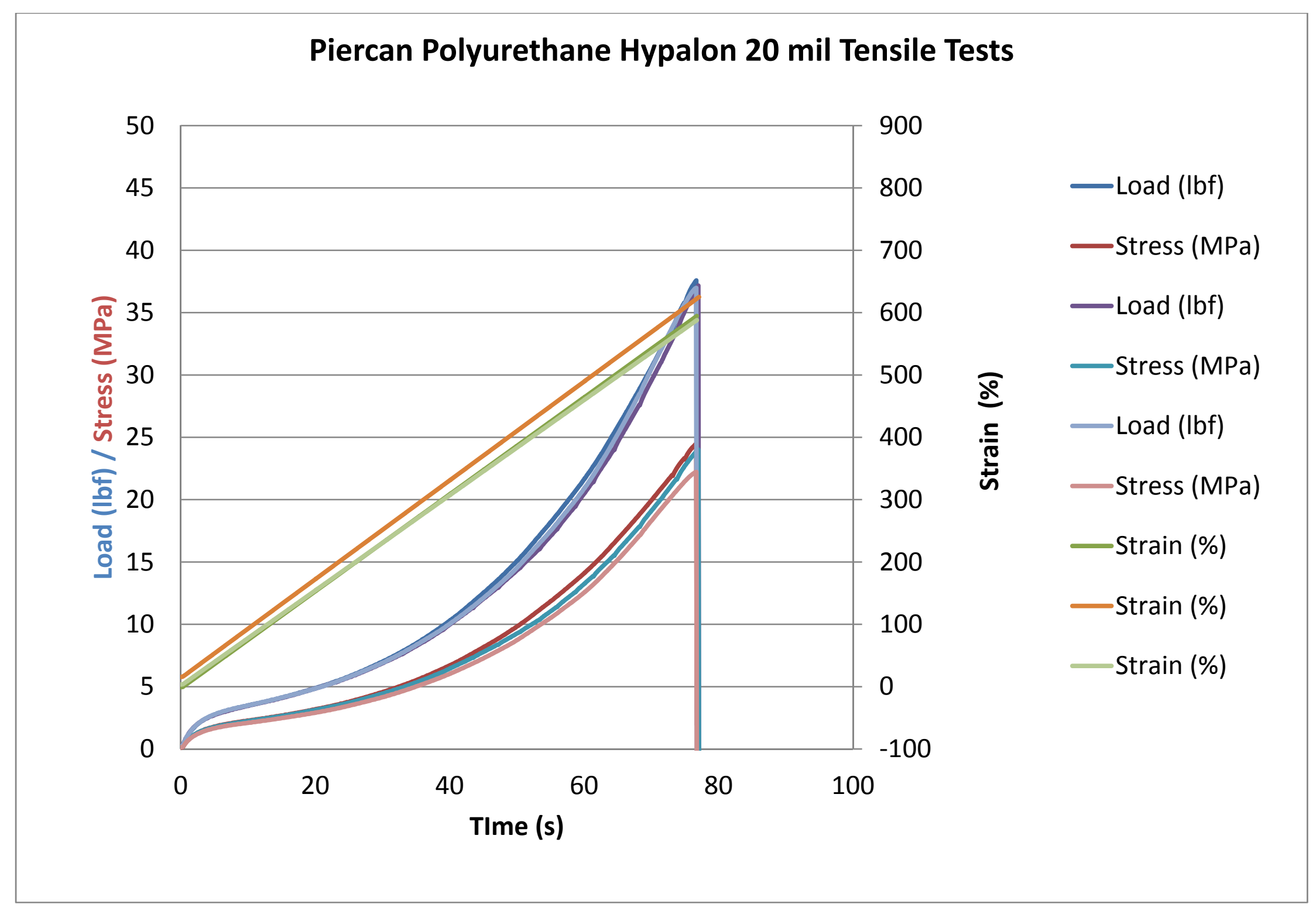

